\title{
Analysis of ICU admissions in a tertiary care setting
}

\author{
M. Poovathi*, N. Prasanna
}

Department of Obstetrics and Gynecology, KAPV Government Medical College, Trichy, Tamil Nadu, India

Received: 02 March 2018

Accepted: 28 March 2018

\section{*Correspondence:}

Dr. M. Poovathi,

E-mail: drmpoovathi@gmail.com

Copyright: (c) the author(s), publisher and licensee Medip Academy. This is an open-access article distributed under the terms of the Creative Commons Attribution Non-Commercial License, which permits unrestricted non-commercial use, distribution, and reproduction in any medium, provided the original work is properly cited.

\section{ABSTRACT}

Background: Management of the critically ill obstetric woman at an ICU is a unique challenge to ICU Physicians and obstetricians. Admission of obstetric patients occur approximately at $0.1-0.9 \%$ of the deliveries. The purpose of this study was to analysis of all critically ill obstetric patients admitted to a dedicated obstetric ICU to characterize the causes, clinical course, treatment any issues engendered by the presence of pregnant and postpartum women in a medical-surgical ICU.

Methods: Details of all patients on the antepartum women or women less than six weeks postpartum admitted to the ICU from January 1, 2017 to December 31,2017 were reviewed. Obstetric data included gestational age at the time of admission and at delivery; type, indication, and location of delivery, and he ICU admitting diagnoses were categoried depending on the major system involved.

Results: Out of a total of 10126 deliveries occurred in MGMGH, Trichy, in the past 1 year from January 2017 to December 2017 out of which the total number of ICU admissions were 141. The preclampsia/eclampsia related complications and Antepartum haemorrhage equally were responsible for the maximum number of obstetric ICU admissions and the number of ICU admissions for ventilator support and haemodynamic support were more.The leading cause of maternal death in the ICU admissions was pre-ecclampsia and eclampsia related complications .Ventilator support was required in 112 patients out of 141 ICU admissions, postpartum admissions were more than the antepartum admissions and nearly 73 of the ICU admissions were delivered by caesarean sections.

Conclusions: The most common precipitants of ICU admission were obstetric hemorrhage and uncontrolled hypertension. Improved management strategies for these problems may significantly reduce major maternal morbidity.

Keywords: ICU admissions, Mortality, Morbidity, Ventilator support

\section{INTRODUCTION}

Maternal mortality and morbidity refects the quality of health care system. Admission of obstetric patients to ICU occur approximately at $0.1-0.9 \%$ of the deliveries. ${ }^{1}$

Clinical recognition of the unique needs of the critically ill obstetric patients have received much attention in an attempt to assess the need for dedicated critical care facilities. For most obstetric patients, rapid recovery follows correction of the acute insult. Overall maternal death rate in the ICU varies from $3.4-21 \% .^{2}$ The challenge faced in the treatment of this patient population are even greater due to the fact that sometimes two lives are endangered simultaneously.

It has been reported that the most common reasons for ICU admission for obstetric patients are hypertensive disorders and massive obstetric haemorrhage. It was found that early detection and prompt referral to tertiary 
centres with intensive care facilities to provide optimum care of circulation, blood pressure and ventilation could minimize the prevalence of multiple organ failure and mortality in critically ill obstetric patients. Our study group revealed a higher rate of obstetric rather than medical complications. From Indian perspective, there are relatively few reports and this study attempts at evaluating the occurrence, indications, course, interventions, and outcome of obstetric patients admitted to ICU of a tertiary referral hospital.

Focusing on audit of obstetric ICUs will help to improve patient care and stimulate education in the management of such patients among the resident doctors, consultants and nursing staff. Formulation of a better scoring system especially applicable to the critically ill obstetric patients could lead to accurate monitoring of quality care and risk stratification for clinical and therapeutic trials.

\section{METHODS}

This is a retrospective study of all the ICU admissions in MGMGH, Trichy in the past 1 year. Details of all patients on the antepartum women or women less than six weeks postpartum admitted to the ICU from January 1, 2017 to December 31, 2017 were reviewed. Obstetric data included gestational age at the time of admission and at delivery; type, indication, and location of delivery and whether the patient has been a referred in for other Cemonc /Primary health centres.

The cases were admitted in ICU based on the criteria mentioned below. A total of 10126 deliveries occurred in MGMGH, Trichy, Tamil Nadu, India in the past 1 year from January 2017 to December 2017.

Number of maternal death during this period in our hospital is 48. Total number of ICU admissions in the last 1 year is 141. Although the majority of obstetric admissions to the intensive therapy unit are postnatal, antenatal cases (the majority of whom are not suffering from conditions directly related to pregnancy) present particular challenges.

Length of time in the ICU, specific interventions, and outcomes were recorded. Mechanical ventilation, central and arterial monitoring, transfusion of blood products, and vasoactive infusions (eg, norepinephrine, dopamine) also were noted.

\section{Inclusion criteria}

- All near miss cases which comes under near miss criteria- Critically ill pregnant, labouring, postpartum and post-abortal women admitted to notified health institutions.

- For identification of an MNM(Maternal near miss cases) case the following criteria (minimum three from each category) must be met with: 1) Clinical findings (either symptoms or signs), 2) Investigations
3) Interventions Or Any single criteria which signifies cardio respiratory collapse (indicated by a heart symbol) as per near miss criteria.

\section{Exclusion criteria}

Pregnant, labouring, post-partum and post-abortal women without risk factors and with low risk factors.

\section{RESULTS}

Out of a total of 10126 deliveries occurred in MGMGH, Trichy, in the past 1 year from January 2017 to December 2017 out of which the total number of ICU admissions were 141 which constitutes $1.36 \%$ the total deliveries.

Table 1: Critical care diagnosis in obstetric ICU admissions.

\begin{tabular}{|c|c|c|c|}
\hline \multicolumn{2}{|l|}{ Diagnosis } & $\begin{array}{l}\text { No. of ICU } \\
\text { admissions } \\
(n=141)\end{array}$ & $\%$ \\
\hline \multicolumn{4}{|c|}{ Obstetric causes } \\
\hline \multirow{2}{*}{$\begin{array}{l}\text { Hypertensive } \\
\text { disorders in } \\
\text { pregnancy }\end{array}$} & $\begin{array}{l}\text { Severe } \\
\text { preclampsia }\end{array}$ & 26 & \multirow{2}{*}{26.24} \\
\hline & $\begin{array}{l}\text { Eclampsia and } \\
\text { complications }\end{array}$ & 11 & \\
\hline \multirow{2}{*}{ Haemorrhage } & $\begin{array}{l}\text { Antepartum } \\
\text { haemorrhage }\end{array}$ & 37 & \multirow{2}{*}{26.24} \\
\hline & $\begin{array}{l}\text { Postpartum } \\
\text { haemorrhage }\end{array}$ & 9 & \\
\hline \multicolumn{2}{|l|}{ CVT } & 4 & 2.8 \\
\hline \multicolumn{2}{|c|}{ Ectopic } & 12 & 8.5 \\
\hline \multicolumn{2}{|c|}{ HELLP syndrome } & 9 & 6.38 \\
\hline \multicolumn{2}{|c|}{ AFLP } & 3 & 2.12 \\
\hline \multicolumn{4}{|c|}{ Non-obstetric causes } \\
\hline \multicolumn{2}{|c|}{ Fever with thrombocytopenia } & 9 & 6.38 \\
\hline \multicolumn{2}{|c|}{ Heart disease } & 9 & 6.38 \\
\hline \multicolumn{2}{|l|}{ DIVC } & 4 & 2.8 \\
\hline \multicolumn{2}{|c|}{ TB } & 2 & 1.41 \\
\hline \multicolumn{2}{|c|}{ Pulmonary embolism } & 2 & 1.41 \\
\hline \multicolumn{2}{|c|}{ Sepsis } & 3 & 2.12 \\
\hline \multicolumn{2}{|l|}{ Anaemia } & 1 & 0.70 \\
\hline \multicolumn{2}{|l|}{ Others } & 6 & 4.25 \\
\hline
\end{tabular}

Table 1 shows the Critical care diagnosis in obstetric ICU admissions of which the preclampsia/eclampsia related complications and Antepartum haemorrhage equally were responsible for the maximum number of admissions. Obstetric complications were a significant cause of severe morbidity as compared to non-obstetric (medical) complications of which obstetric haemorrhage was found to be a significant risk factor for ICU admission. Fever with thrombocytopenia and heart disease constituted to the majority of non-obstetric causes of ICU admission.

Table 2 shows total number of ICU admissions requiring ventilator support and out of the total ICU admissions of 141,112 required ventilator support. 
Table 2: ICU admissions requiring ventilator support and its outcome.

\begin{tabular}{|llll|} 
Month & $\begin{array}{l}\text { No of patients } \\
\text { requiring } \\
\text { ventilator } \\
\text { support }\end{array}$ & $\begin{array}{l}\text { No. of } \\
\text { patients } \\
\text { expired } \\
(48)\end{array}$ & $\begin{array}{l}\text { No. of } \\
\text { patients } \\
\text { recovered } \\
(64)\end{array}$ \\
\hline January & 12 & 3 & 9 \\
\hline February & 6 & 1 & 5 \\
\hline March & 6 & 4 & 2 \\
\hline April & 4 & 3 & - \\
\hline May & 14 & 11 & 3 \\
\hline June & 13 & 4 & 9 \\
\hline July & 14 & 3 & 11 \\
\hline August & 1 & - & 1 \\
\hline September & 7 & 5 & 2 \\
\hline October & 13 & 9 & 3 \\
\hline November & 10 & 3 & 9 \\
\hline December & 12 & 2 & 10 \\
\hline
\end{tabular}

Table 3: Maternal death in ICU and its causes.

\begin{tabular}{|lll|}
\hline $\begin{array}{l}\text { Maternal death } \\
\text { causes }\end{array}$ & $\begin{array}{l}\text { Number of } \\
\text { deaths }(\mathbf{n = 4 8})\end{array}$ \\
$\begin{array}{lll}\text { Ecclampsia and } \\
\text { related } \\
\text { complications }\end{array}$ & 6 \\
\cline { 2 - 3 } & $\begin{array}{l}\text { HELLP } \\
\text { syndrome } \\
\text { Acute pulmonary } \\
\text { edema }\end{array}$ & 6 \\
\hline PPCM & 4 \\
\hline Fever with thrombocytopenia & 1 \\
\hline AFLP & 6 \\
\hline CVT & 4 \\
\hline DIC & 3 \\
\hline Severe anaemia and failure & 4 \\
\hline Pulmonary embolism & 1 \\
\hline Sepsis & 4 \\
\hline Respiratory diseases (TB, pneumonia) & 2 \\
\hline Heart disease complicating & 2 \\
\hline Glycogen storage disorder & 1 \\
\hline Appendicular perforation & 1 \\
\hline
\end{tabular}

Table 3 shows the leading cause of maternal death in the ICU admissions of which pre-ecclampsia and eclampsia related complications were responsible for majority of ICU deaths $(n=17)$. The next most common cause for maternal death in ICU was found to be fever with thrombocytopenia (a non-obstetrical cause). The mortality rate among ICU admissions was $34.04 \%$.

Table 4 shows the interventions required for patients in the ICU and it was found the ventilator support was required in 112 patients out of 141 ICU admissions. followed by vasoactive infusions $(n=77)$.

Table 5 shows the different periods of admission to the ICU and it was found that postpartum admissions $(n=107)$ were more than the antepartum admissions $(n=34)$ and nearly 73 of the ICU admissions were delivered by caesarean sections.

Table 4: Interventions in the intensive care unit.

\begin{tabular}{ll} 
Intervention & Number \\
Central line & 55 \\
\hline Blood transfusion & 52 \\
\hline Mechanical ventilation & 112 \\
\hline Vasoactive infusion & 77
\end{tabular}

Table 5: Period of admissions to ICU.

\begin{tabular}{|ll|}
\hline Period of admission to ICU & No. Patients \\
\hline Admitted antepartum & 34 \\
\hline Admitted postpartum & 107 \\
\hline Discharged undelivered & nil \\
\hline Delivered before admission to ICU & 27 \\
\hline Delivered in ICU bed & 7 \\
\hline Cesarean section (all emergent) & 73 \\
\hline
\end{tabular}

Table 6 shows the various indications for mechanical ventilation acute respiratory failure $(n=53)$ and haemodynamic failure $(n=44)$ were responsible for most of the cases requiring ventilator support.

Table 6: Indication for mechanical ventilation.

\begin{tabular}{|ll|}
\hline Indication & Number \\
\hline Acute respiratory failure & 53 \\
\hline Haemodynamic failure & 44 \\
\hline Impaired consciousness & 10 \\
\hline Postoperative ventilation & 5 \\
\hline
\end{tabular}

\section{DISCUSSION}

The American College of Critical care Medicine and the Society of Critical care medicine has published the following guidelines for critical care. ${ }^{3}$ Of this, the most common cause for ICU admissions is Medical or surgical ICU-most critically ill patients requiring ventilator support, invasive monitoring or pharmacological support for circulation are transferred to ICU. Second comes The Obstretic Intermediate Care Unit Or The High Dependency Unit - these units are for the patients who do not require intensive care but who require a higher level care than provided in the general wards. Third comes The Obstretric intensive care unit-these are full care units operated by obstetrician and anaesthetist. Very few centres have these facilities and ours is one among them. The total number of deliveries in our hospital in the past one year is 10126 and the total number of ICU admissions in obstetrics in the past 1 year is 141 .

Criteria for admission in ICU. ${ }^{4}$

- Obstetric patients with decompensated function of medical diseases -cardiac, pulmonary, renal, 
endocrine, neurological,haematological, hepatic, immune

- Obstetric patients with obstetric complication like severe pre-ecclampsia,DIC, pregnancy related sepsis,amniotic fluid embolism

- trauma to obstetric patients requiring invasive haemodynamic monitoring

- pregnant patients with toxic insult /poisoning/drug overdose

- All pregnant patients requiring invasive haemodynamic monitoring

Multidisciplinary team (Skilled and experience obstetrician as consultant, Senior resident on floor duty ,Intensivists, Respiratory Therapist, Trained and skilled Nursing staff, Clinical Pharmacist, Ancillary Staff) shall coordinately work and provide, protocol driven care, assist in critical care decision taking, going ahead with the processes along with having common goal to provide optimal, quality and evidence based care to the critically ill patient. ${ }^{5}$ Staffing pattern should be should be 1:1 nurse to patient ratio. ${ }^{6}$ At times it may be $2: 1$ in cases of unstable patients. Unplanned admission to an ICU is an accepted quality-assurance indicator for gynecology patients. 12 We suggest that unplanned admission to the ICU is an equally useful quality-assurance indicator in obstetrics. One of the advantages of using obstetric admission to the ICU as a quality-assurance indicator is that it allows analysis of a meaningful number of seriously ill patients. ${ }^{7} 75$ percent of the women admitted to the ICU in this study were postpartum. There are at least two possible explanations for this finding. It is wellknown that in the postpartum period, there are significant hemodynamic changes, including 65percent increase in cardiac output, acute blood loss at delivery, and a decrease in plasma protein oncotic pressure. ${ }^{8}$

The need for mechanical ventilation and haemodynamic support was the major indication for antenatal ICU transfer. ${ }^{9}$ Thus, in our institution, mild to moderate hemodynamic instability is manageable in the labor and delivery unit by coordination of the anesthesia and obstetric staff Once the patient has delivered, the criteria for transfer are liberalized, reflecting that the specialized services associated with fetal assessment and delivery are no longer a priority. ${ }^{10}$ It is obvious that these cardiovascular dynamics may exacerbate symptoms in patients with underlying cardiovascular or pulmonary dysfunction whether of medical or obstetric origin. A second possible explanation for the higher number of postpartum ICU admissions reflects a reluctance to move a pregnant woman away from the expertise of obstetric personnel, unless it is absolutely necessary. When women with viable pregnancies are in the ICU, issues beyond usual critical care arise. Most importantly, fetal monitoring must be addressed. Unfortunately, if the mother is critically ill, any decrease in organ perfusion or oxygen saturation may adversely affect the fetus. Presuming one has access to the maternal abdomen, continuous electronic fetal monitoring is possible.
However, interpretation of these fetal monitor strips, both fetal heart rate pattern and contraction pattern, require expertise not usually expected in an ICU nurse or physician. ${ }^{11}$ To further ensure adequate fetal surveillance, whenever possible, a labor and delivery nurse , a house surgeon along with a postgraduate aids in the care of women in the ICU with a viable pregnancy

Obstetric ICU admissions indicate how well, or how poorly, our team has provided necessary care. The contribution of suboptimal care to subsequent admissions to the ICU has been studied. We suggest that regular review of maternal ICU admissions should be done by those involved in obstetric care. Few physicians have much experience with such cases, yet they often arise unexpectedly and necessitate decisive action. Efforts to improve the management of postpartum hemorrhage and hypertensive disorders are most likely to yield significant improvements in patient care because these are the most common causes of major maternal morbidity.

\section{CONCLUSION}

The most common precipitants of ICU admission were obstetric hemorrhage and uncontrolled hypertension. Improved management strategies for these problems may significantly reduce major maternal morbidity. Authors suggest that regular review of maternal ICU admissions should be done by those involved in obstetric care.

\section{ACKNOWLEDGMENTS}

Authors would like to thank Dean, Government K.A.P.V Medical College and Hospital, Trichy for his support during study. Authors also would like to thank all the medical and para-medical staffs, all the patients who have supported this study.

\section{Funding: No funding sources Conflict of interest: None declared \\ Ethical approval: The study was approved by the Institutional Ethics Committee}

\section{REFERENCES}

1. Knaus WA, Wagner DP, Zimmerman JE, Draper EA. Variation in mortality and length of stay in intensive care units. Ann Intern Med. 1993;118:75361.

2. Clark SL, Cotton DB. Clinical indications for pulmonary artery catheterization in the patient with severe preeclampsia. Am J Obstet Cyneeol. 1988;158:453-8.

3. Clark SL, Horenstein JM, Phelan 1, Montag T, Pdul RH. Experience with the pulmonary artery catheter in obstetrics. Am J Obstet Cyneeol. 1985;152:374-8

4. Mabie VC, Sibai BM. Treatment in an obstetric intensive care unit. Am J Obstet Gynecol. 1990;162:1-4. 
5. Cunningham FG, MacDonald PC, Gant NF, Leveno KJ, Gilstrap LC III, Hankins GDV, et al. Williams obstetrics. 20th ed. Stamford, Connecticut: Appleton \& Lange, 1997.

6. Department of Health. Report on confidential enquiries into maternal deaths in the United Kingdom 1991-1993. London: Her Majesty's Stationary Office, 1996.

7. Petros AJ, Marshall JC, van Saene HK. Should morbidity replace mortality as an endpoint for clinical trials in intensive care? Lancet. 1995;345:369-71

8. Drife JO. Maternal "near miss" reports? BMJ 1993;307:1087-8.
9. Scarpinato L. Obstetric critical care. Crit Care Med 1998;26:433.

10. Collop NA, Sahn SA. Critical illness in pregnancy. An analysis of 20 patients admitted to a medical intensive care unit. Chest 1993;103:1548-52.

11. Kilpatrick SJ, Mathay MA. Obstetric patients requiring critical care. A five-year review. Chest 1992;101:1407-12.

Cite this article as: Poovathi M, Prasanna N.

Analysis of ICU admissions in a tertiary care setting. Int J Reprod Contracept Obstet Gynecol 2018;7:1831-5. 